http://sajie.journals.ac.za

ISSN 1012-277X S.Afr.j.ind.eng.

S A Tydskrif vir Bedryfosingenieurswese, Vol 8, No 2, Desember 1994, pp1-24
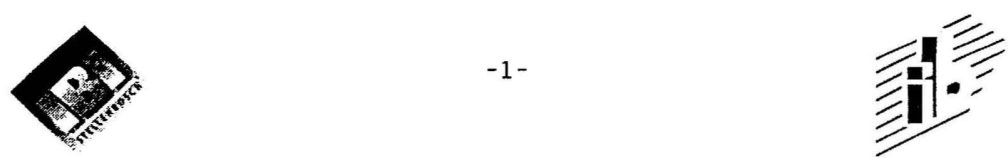

\title{
THE INDUSTRIAL ENGINEER: CAUGHT BETWEEN TWO REVOLUTIONS?
}

\author{
(1) Prof. Niek Du Preez \\ (2) Prof. Liliane Pintelon
}

(1) University of Stellenbosch, Institute for Industrial Engineering, South-Africa

(2) KU Leuven, Center for Industrial Management, Celestijnenlaan 300A, 3000 Leuven, Belgium 


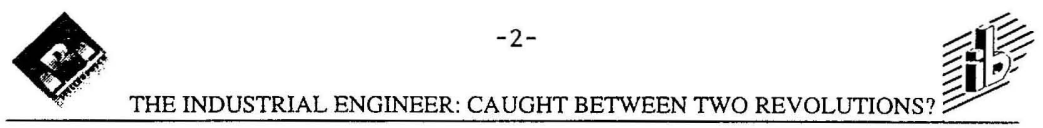

\section{ABSTRACT}

The Industrial Engineer is caught between the Industrial Revolution and the Information revolution. $\mathrm{He}$ is confronted with choosing between pragmatic improvements in productivity and efficiency of a single operation or the opportunistic modelling and reshaping of the networked "virtual enterprise" to become more competitive in a global marketplace. The diagram below depicts the different extremes of the Industrial Engineering timeline. This implies that the two societies (Industrial and information) might have conflicting characteristics which requires careful repositioning of the Industrial Engineer to ensure that the benefits that can be obtained from the two societies are maximised.

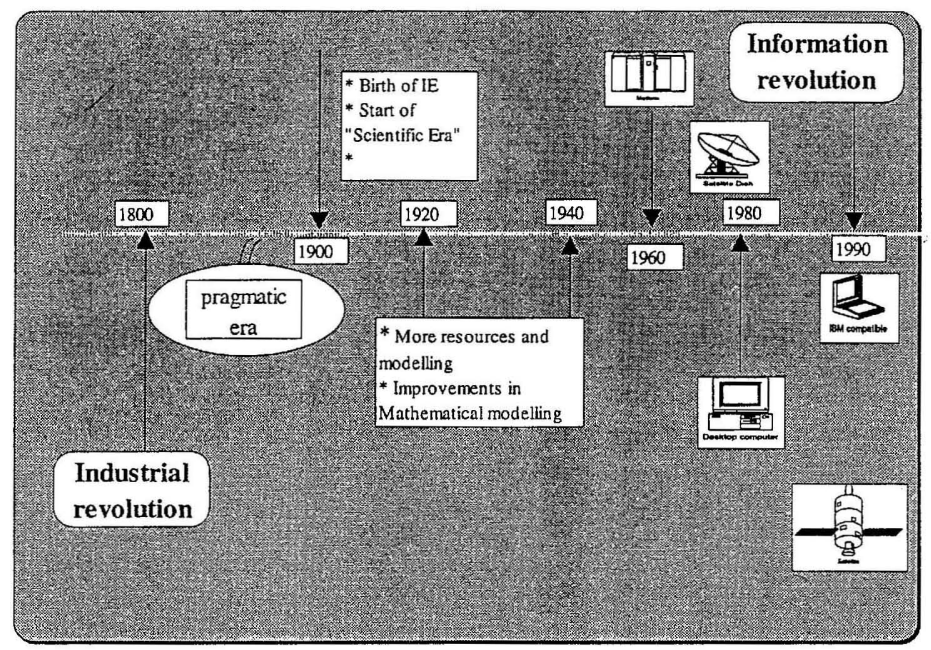

FIGURE 0.1: The development-line of the two revolutions.

This paper documents the development of Industrial engineering, then evaluates the nature of the much publicized Information revolution and its impact on society. In order to establish the nature and composition of contemporary Industrial Engineering in the 1990's, an analysis and categorization of the literature in four journals for the last two years are performed. This is enhanced with an INTERNET search into Industrial Engineering Research and developments that are currently under development.

From these results the similarities and differences of the two revolutions and the characteristics of the two societies are compared. The authors then identify some opportunities and some threats for the Industrial Engineer and concludes that a combined approach is applicable and necessary. The Industrial Engineer can not afford to ignore the key concepts of either of the two societies. 


\section{INTRODUCTION}

Industry and Industrial Engineering are in a continuous process of improvement (KAIZEN- Japanese word for continuous incremental improvement effort) and changes to standard operating procedures and work methods are the norm rather than the exception. The move toward more holistic modelling and integration is manifesting itself in new approaches or "buzz words" like "Enterprise engineering", Business process "Re-engineering" and "Concurrent Engineering". These are all based on and facilitated by rapid improvements in the functionality and growth of information technology. The extend to which information technology is impacting industry, but also the normal citizen has culminated into an era that is compared by various authors as "The Information Revolution".

Some authors equate this to a "Rubicon" of similar importance than that of the Industrial Revolution that started in 1785 in England, about 1800 in the U.S.A. and about 1825 in Europe. The key issue is change and the information revolution is instigating change of substantial magnitude, primarily in the area of manipulation of information, re-use of designs and networking of resources. Key concepts of this era are the knowledge worker, the global village and empowering developments in power and ease of use of computer software that are utilised by the information society. These developments led to an era with a strong focus also on Computer Assisted Learning and the development of substantial amounts of educational courseware.

The Industrial Engineer, with his knowledge of the Systems Engineering approach, Information Technology, Manufacturing Technology and integration of system components, is well positioned to be a major agent of change in this new revolution.

This article provides an overview of the development of Industrial Engineering since the Industrial Revolution. It categorises the development of Industriál Engineering into five phases and discusses some of the impacts of the Information Revolution on the profession. In conclusion some opportunities and also some threats are listed as perceived relevant to Industrial Engineering.

\section{INDUSTRIAL ENGINEERING TIMELINE}

Industrial Engineering focuses on creation of wealth and improved utilization of all resources (Salvendy 1992.) The development of the profession in striving to achieve these goals can be divided into five phases:

- INITIATION AND ESTABLISHMENT PHASE(1746-1901)

- PHASE FOR ESTABLISHING A PRAGMATIC BASE (1875-1950)

- PHASE FOR ESTABLISHING A SCIENTIFIC BASE (1930-1960)

- PHASE FOR ESTABLISHING A VIRTUAL LABORATORY (1960-1989)

- EMPOWERMENT OF SYSTEMS EXPERIMENTATION THROUGH MATURE MODELLING AND COMPUTING PHASE (1990 - current) 
Some of the major events and milestones in the development of the Industrial Engineering profession are summarised below.

\subsection{INDUSTRIAL REVOLUTION}

The Industrial revolution initiated much of the birth and initial development of the Industrial Engineering profession.

Some of the great breakthroughs in achieving the aims of improvement of wealth and optimal utilization of resources were the harnessing of energy (steam in 1764 and electricity in 1812 and internal combustion liquid fuel in 1876). Improving Manufacturing Technology, inter-changeability of parts and accurate machine tools introduced the era of the manufacturing engineer with big contributors like Maudsley (1810) and Henry Ford in the 1900's.

These events triggered the development of an industrial society with the following characteristics:

INDUSTRIAL SOCIETY

- Specialization of labour

- Mechanical and electrical energy

- Standardization and interchangeable parts

- Precision from machines, not men

- Mass production (the assembly line) and mass demand

- Management typified by an internally focused functional hierarchical burdened bureaucracy

\subsection{ESTABLISHING AN IDENTITY}

The involvement of engineers and scientists in the industrialization activities led to the term Industrial Engineer early in the 1900's. The following subsequent developments and contributions are relevant.

Harnessing the human as a production resource by providing the correct work methods, tools and work categories, further led to improved productivity. The contributions of Frank and Lillian Gilbreth in 1885 and Taylor and Hollerith in 1898, are important milestones.

The practitioners of Industrial Engineering evolved from purely pragmatic problem solvers to more scientific designers and improvers' of production systems by the publication of research and development material.

\subsection{BECOMING SCIENTIFIC}

An important contribution in the process of developing a scientific base is the improved understanding of management of production activities. This was documented by F.W. Taylor's book, "The principles of scientific management" in 1911. 
The second world war focussed much more resources on scientific development work of the man-machine interface, specifically for fighter pilots and operations research applications in search theory. This is generally believed to have led to a Rubicon for the Industrial Engineer in the sense that he has evolved from an empirical pragmatist to a scientific mathematically supported design and integration engineer.

Another important development was the inception of the total quality management drive that started just after the second world war in Japan. The work of Deming and Juran is still considered of great importance today.

\subsection{ESTABLISHING AN ELECTRONIC LABORATORY}

The advent of the digital computer in the 1960's introduced a new era which enabled the Industrial Engineer to experiment with production systems in a "virtual laboratory". Although crude at the start, it made it possible for the Industrial Engineer to experiment with transformation system components without disrupting actual systems or building full sized or scaled (physical) actual experimental setups.

The ability to "model" and experiment with the Real world was greatly enhanced by the understanding of large production systems and the complexities of planning such production systems.

Understanding of complex production systems also increased. In 1973 Toyota motor company implemented the Just-in-Time production system that focused on reducing the variability in the production process and adding value not before it is required. Materials requirement planning (MRP) and Manufacturing Resources Planning (MRP II) became widely publicized and were also used to some extent for planning the production of products with a time dependent demand pattern.

\subsection{PERSONAL COMPUTING: A NEW TOOL}

The advent of the personal computer in the early 1980's gave new meaning to the concept of "desk top laboratory experimentation". This development empowered the Industrial Engineer to not only experiment, but also increasingly manage large transformation systems efficiently and in more detail. The development of the personal computer and its competitive pricing structures led to major computerization of production and service industries. It also changed the face of the secretarial functionality in the organization. The growth and level of maturity of software in the fields of Linear Programming and general system simulation with graphical user interfaces moved the systems experimentation from the research and development environments of the universities and research institutions to the production environments of larger corporations and general Industrial Engineering consultants.

\subsection{NETWORKING: ESTABLISHING CONNECTIVITY}

The improved communications through computer, telephone and transportation networks greatly contributed towards collaboration not only in research and development, but also in production operations. 
http://sajie.journals.ac.za

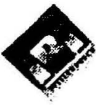

Global competition and inter-company performance evaluation or benchmarking and concurrent engineering introduced concepts of sharing knowledge. also between competitors which led to improved products and lower cost. (It also neutralised some of the non-productive organisations.)

\subsection{REACHING MATURITY - ENGINEERING THE WHOLE ENTERPRISE}

The Industrial Engineering function of designing and managing transformation processes reached maturity when computerization and connectivity made it possible to design and manage enterprise as a whole rather than components of the enterprise in somewhat isolated fashion. Although these developments made the task of the Industrial Engineer more complex. It also enabled him/her to re-use, integrate and access information and resources globally, and extend human abilities with less effort through the computer and its networking and modelling abilities.

It is relevant to this discussion to briefly evaluate some of the characteristics of the Information Revolution as this is probably the biggest contributor to empower mature Industrial Engineering on enterprise level.

\section{INFORMATION REVOLUTION}

Stewart (1994, p55) highlights a number of characteristics and initiating developments of the information revolution. Although the numbers have changed, it still provides a concise summary of certain trends. These are briefly listed below:

\subsection{SURPASSING INDUSTRIAL AGE INVESTMENTS}

Capital investment in the "Industrial age" (Industrial equipment, machinery for services, mining, oil fields, agriculture and construction (Except tractors) \} of $\$ 120$ Giga-dollar was equaled in 1991 by capital investment in "information age" \{Computers and communications equipment\}.

\subsection{FACILITATING CONNECTIVITY: THE FIBRE-OPTIC CABLE.}

The $2 \mathrm{Mbit} / \mathrm{sec}$ transfer rate ceiling of copper was removed with the introduction of glass cable. In 1992 North American manufacturers shipped more than 5 million kilometers of fiber-optic cable.

\subsection{ESTABLISHING INTER-CONNECTIVITY - THE INTERNET}

The ability to communicate through computer networks was born in 1956 when the Russians launched Sputnik (the first artificial earth satellite) and the USA formed ARPA (Advanced Research Projects Agency) to establish US lead in science and technology applicable tō military.

In 1969 ARPANET was commissioned with the first nodes at leading Universities such as the Stanford Research Institute. In 1973 the first international connections to the ARPANET were made to England and Norway. 
In September 1994 approximately 38 million individuals in the USA and Europe have access to the INTERNET. Thirty per cent of American households has a computer and more than 60000 US companies exchange data electronically.

It is estimated that by 1998 data communications business will be of the order of $\$ 40$ Giga-dollar per year as the flow of electrons replaces a flow of funds and goods.

\subsection{EMPOWERING THE KNOWLEDGE WORKER - MATURE COMPUTING SOFTWARE}

The maturity level of general office software like MICROSOFT OFFICETM, WORDPERFECT OFFICETM and Information integration software such as Lotus Notes $^{\mathrm{TM}}$ has changed the nature of tasks in the office and home. Availability of a general encyclopedia like MS ENCARTA ${ }^{\mathrm{TM}}$ (representing some 500 person years in development work) has made information available to every person with access to a computer. It is no longer the person who can find the right information that will win the "race", but rather that person who can synthesize or ad value by combining and presenting multiple sources of applicable information. This should be integrated with sound scientific analysis and engineering problem solving expertise.

\subsection{FACILITATING RE-USABILITY - INFORMATION CLEARINGHOUSES}

The business of finding the right information in an era where knowledge is doubling at a rate of once in ten years, has also been addressed. "An information Clearinghouse Server for Industry consortia" is the title of a paper presented by Smithson and Singer at the Fall 1994 World Wide Web Conference. It outlines the initiatives of Enterprise Integration Technologies in setting up a WWW-based information system to support organization in disseminating marketing information to Industry. This type of service of supplying the right information will expand and become more important and will impact the Industrial Engineering profession.

\subsection{FACILITATING HUMAN RESOURCE DEVELOPMENT PROGRAMMES}

The importance of the information revolution to Research and Development and teaching has been identified by the leading nations of the world. The substantial investment of the USA, UK and European Economic Community in Computer Assisted Learning and training programmes and general use of the computer in research and developmental work is producing some very useful material and software. These could further empower individuals to make even bigger contributions to the creation of wealth. The Industrial Engineer responsible for human resource development should stay informed about available resources of such a nature. Initiatives such as the CTI (Computers In Teaching Initiative), and TLTP (Teaching and Learning Technology Programme) of the British Government, produce material and coordinate information on applicable software in different disciplines. 


\section{RESEARCH AND DEVELOPMENT and INDUSTRIAL ENGINEERING (R\&D)}

The Information revolution also made its impact on research and development in the field of Industrial and systems engineering. The author researched these developments as visiting professor at the catholic University of Leuven.

To establish the general trends in Industrial Engineering applications, a categorization of the topics of most recent publications in the following journals was made:

- Industrial Engineering,

- Harvard Business Review,

- Fortune International,

- Logistics Information Management.

The different titles were categorized into five major categories as indicated in figure 4.1 below.

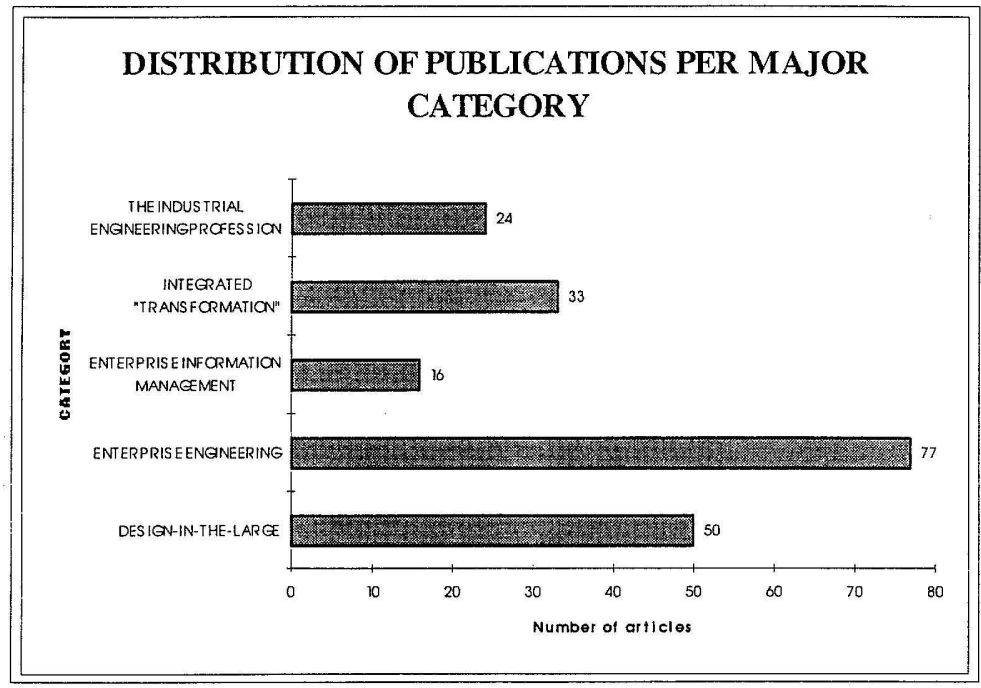

Figure 4.1: Distribution of major categories of Industrial Engineering applications.

The different titles were further divided into secondary subject areas as summarised in tables in APPENDIX A. The main category headings are:

- The Industrial Engineering profession which dealt with profession related issues.

- Integrated Transformation Engineering which dealt with the design and improvement of the transformation or production process. 
- Enterprise Information Engineering that dealt with issues concerning information and information management and the enterprise.

- Enterprise Engineering which dealt with designing and improving the enterprise and its components.

- Design In The Large that addresses product design, manufacturability and maintainability.

In addition to the analysis of articles in journals, the CYBERSPACE was searched for contemporary research and developmental work in the field of industrial and systems engineering. The rationale behind this decision is that the lead-time for papers and articles in Industrial Engineering journals is shorter than that of text books, but substantially longer than that of electronic media sources. Apart from the global systems approach and focus on the enterprise as a design unit, some very interesting Research and Development activities were found. Three of these will be discussed briefly.

\subsection{STANFORD UNIVERSITY: THE SHARE PROJECT}

This project focuses on a Scalable Framework and Methodology for Concurrent Engineering. The objectives of the project are to facilitate "teams of engineers to achieve a shared understanding of their designs and design processes, using agentbased computational tools and services for communication, collaboration, analysis and synthesis." The approach is to develop sharable design representations that also contain the decisions and rationale associated with the specific artifact. A distributed architecture enables human and computational agents to communicate and cooperate in solving engineering problems. The development of incremental, interactive concurrent engineering tools for analysis and synthesis is therefore relevant.

The SHARE environment was used by 15 teams working on industry sponsored projects using the INTERNET. Seventeen different industrial groups were involved in this testing and electronic documents were delivered to industrial sponsors as a design library using the World Wide Web. (Cutkosky, M.R. et al. 1994) See Figure 4.1. 


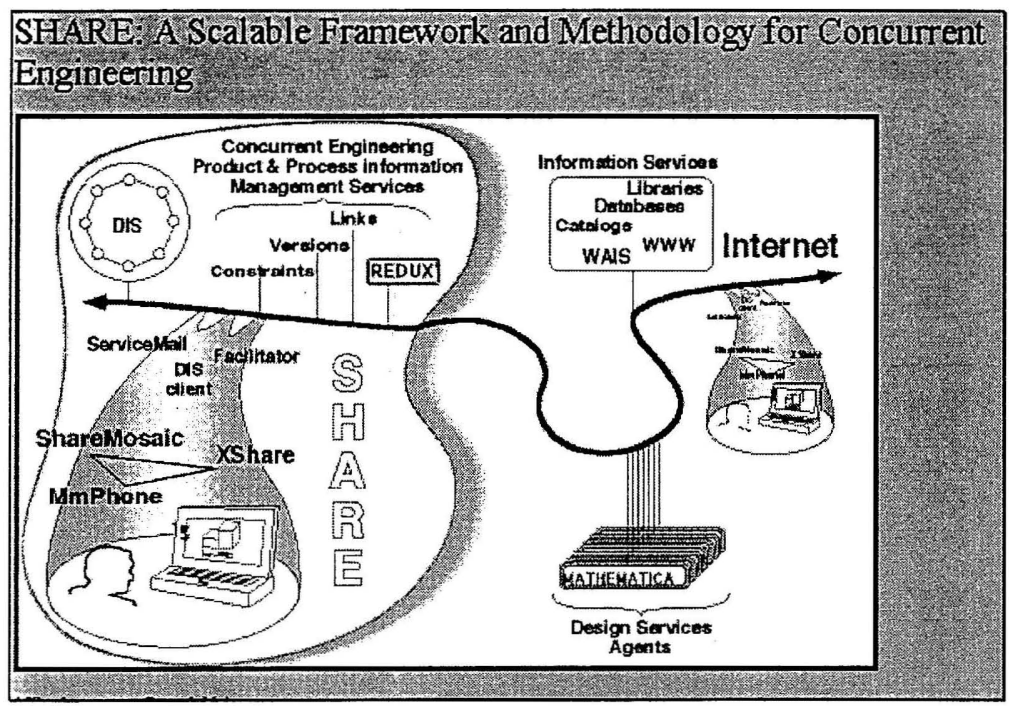

FIGURE 4.1 Diagram of the SHARE project structure.

\subsection{UNIVERSITY OF TORONTO: Integrated Supply chain management}

Another interesting Industrial Engineering activity is research and development on integrated Supply Chain management at the university of Toronto in Canada.

The goal of this project is "focuses on the control side of managing the supply chain. In particular, the goal is to create a set of intelligent agents that can cooperatively perform supply chain management functions in real time." This project aim to go beyond MRP and MRP II, and develop more sophisticated planning and scheduling algorithms to manage the total supply chain with improved overall quality of management. Interactions between agents in the supply chain are also addressed to accommodate the dynamics of the logistics systems within the supply chain. PROLOG ${ }^{\mathrm{TM}}$ axioms will be used to develop a generic model.

Figure 4.2 below depicts the different components in the logistics system of the supply chain. 


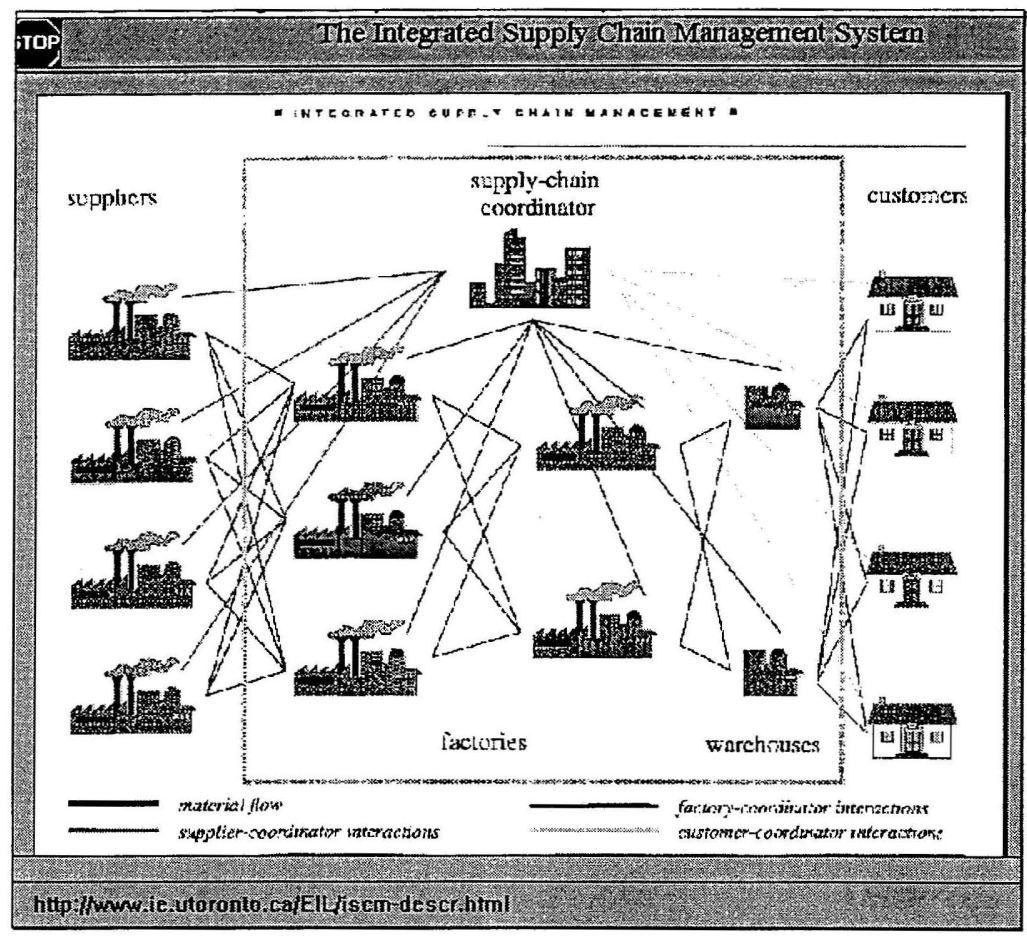

Figure 4.2 Integrated supply chain management

\subsection{The AIMS project: Agile Infrastructure for Manufacturing Systems}

This project is a collaborative effort by Lockheed, General Motors, Martin Marietta and Texas Instruments to create an Agile Manufacturing Infrastructure in the USA Defense and non-defense industries and illustrate its effectiveness in daily production.

The purpose of the AIMS project is to enhance the USA competitiveness and defense readiness by unifying its commercial industrial base and its defense manufacturing base through a common information infrastructure. It will further allow the manufacturers and suppliers of the USA to "focus on core competencies without sacrificing on breadth of capability."

AIMS will encompass business processes, information technology and manufacturing technology in an integrated approach as is depicted in figure 4.3 below. The AIMS project will use a network of certified manufacturing services linked via the INTERNET. The certification of suppliers is based on standardised business processes, product data formats and network interfaces as depicted in figure 4.3. 

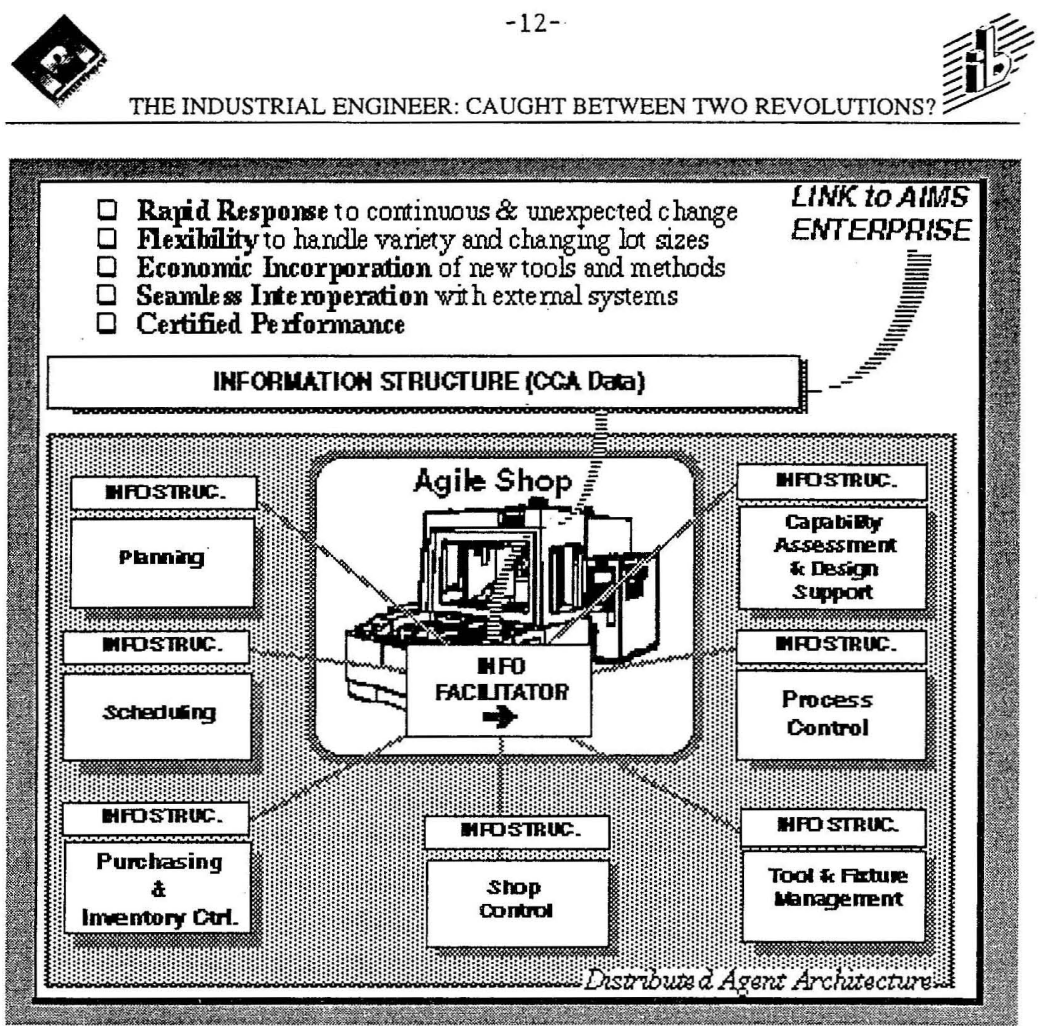

Figure 4.3: A certified Manufacturing service (electronically copied from Park et al.)

"Thirty years of Cold War have left the US with two parallel industrial infrastructures - one for defense, the other for general commerce. Each sector relies on distinctive technologies, production processes, and business practices. This legacy has made defense systems unaffordable and encumbered our industrial competitiveness. The new world order demands a unified industrial base where defense and commercial products share dual-use technology and are manufactured on agile production processes that respond rapidly to changes in customer requirements and demand." (As is motivated by Hisup Park, Jay M. Tenenbaum, Rick Dove "Agile Infrastructure for Manufacturing Systems (AIMS), A Vision for Transforming the US Manufacturing)

The different agent of the AGILE infrastructure then provides service to the "virtual corporation" or Agile Enterprise as is depicted in figure 4.4. 
http://sajie.journals.ac.za
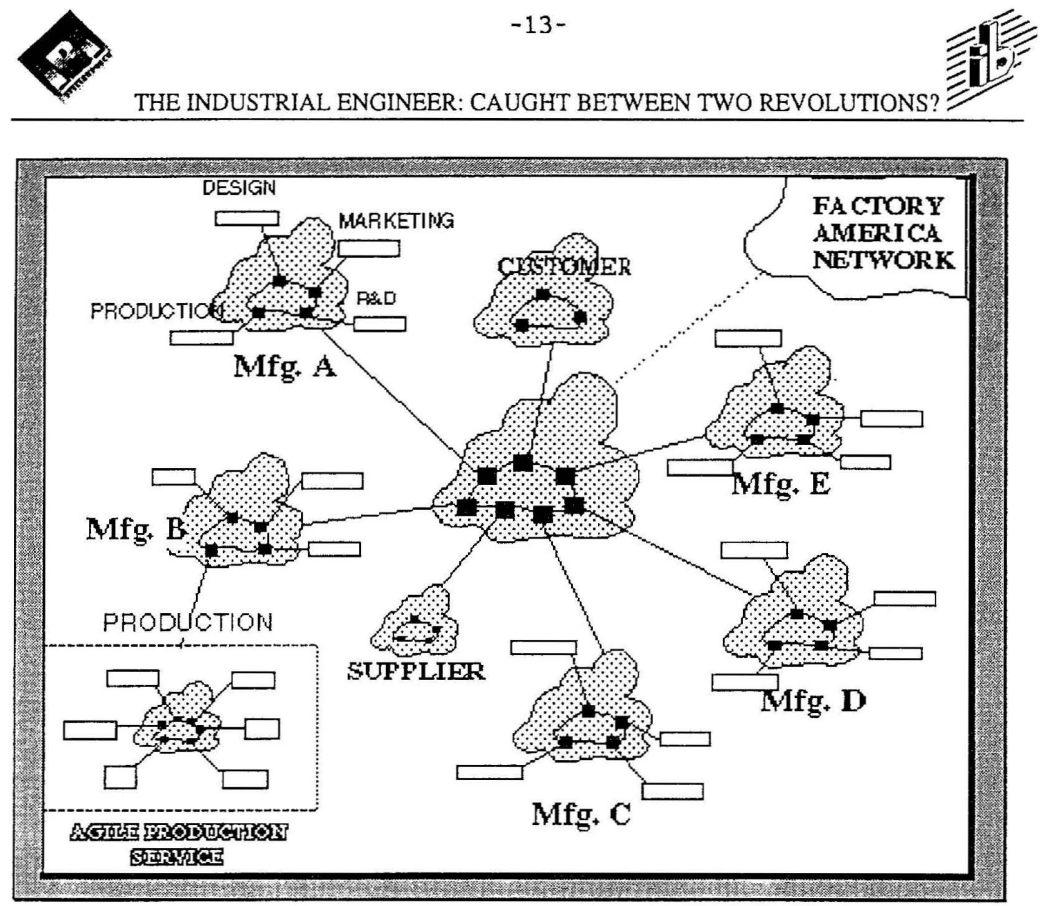

FIGURE 4.4: Agile Enterprise (Virtual Corporation) (electronically copied from Park et al)

The communication for human and computer interaction is performed by e-mail and the INTERNET as is depicted in the diagram of figure 4.5. 


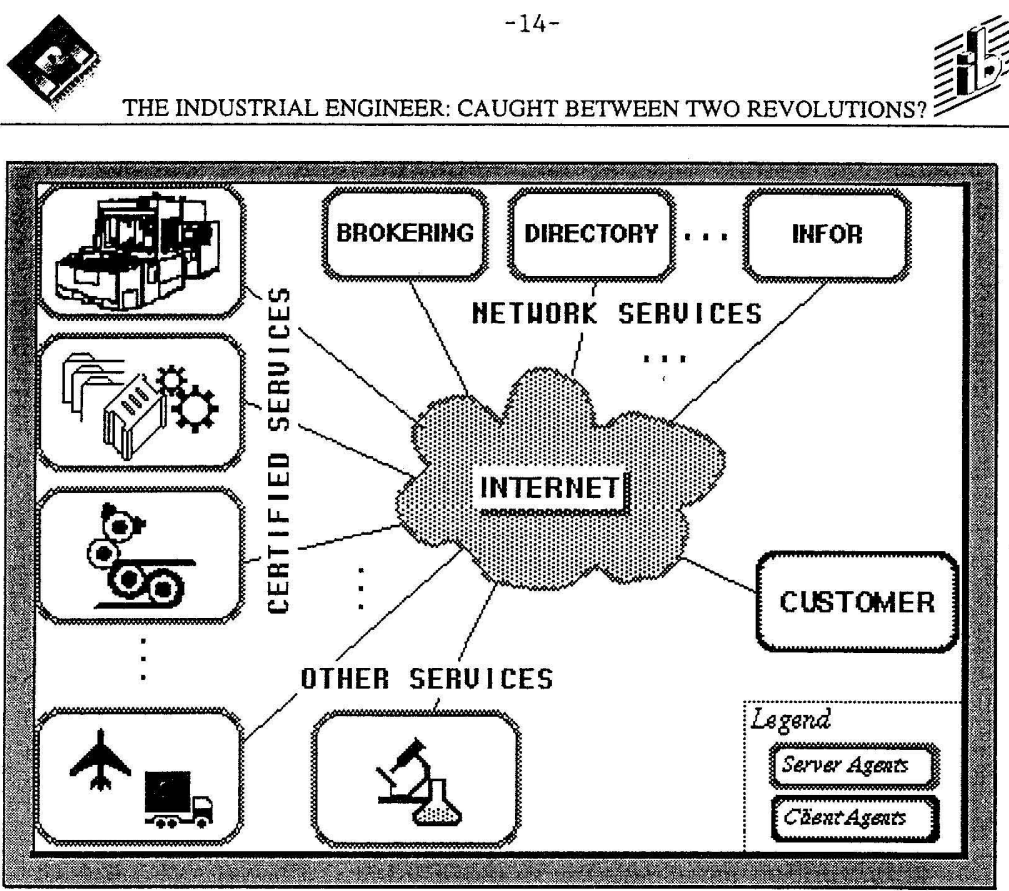

FIGURE 4.5: Network services (electronically copied from Park et al.)

From the above three examples two important insights were developed:

1. The maturity levels of the Industrial Engineer to design and improve on enterprise or even international levels are attributable to technologies of the information revolution with the communication function of the INTERNET of paramount importance.

2. The benefits of using the INTERNET to obtain and provide Research and Development information, but also to obtain a competitive edge in industry, is not realized at all. The Industrial Engineer in both research and development, but similarly in normal industry, cannot afford not to make full use of the tools that is provided by the information revolution.

It is, however, crucial to understand the characteristics of the information age and the subtle changes that is implied by it, as well as the similarities between the Information revolution and the Industrial revolution of 100 years ago. These will be briefly discussed in the following paragraphs. 


\section{KEY CONCEPTS OF THE TWO DIFFERENT SOCIETIES}

The following are some of the key concepts of the two societies:

\subsection{INDUSTRIAL SOCIETY}

The Industrial society of the past 100 years was developed, as indicated in 2.1, around:

- Specialization of labour; Harnessing of energy; Standardization and interchangeable parts; Precision from machines, not men; The assembly line with mass production and mass demand and an Internally focused functional hierarchical burdened bureaucracy

\subsection{INFORMATION SOCIETY}

In sharp contrast, the characteristics or key concepts of the Information age are:

- The Global village: Through networked computers it is possible for the knowledge worker to add value practically from any convenient spot on the globe.

- Knowledge worker: More and more people are self-employed and are working through "gray muscles" rather than conventional hand labour.

Life long learning: The rates at which new knowledge is developing and made available to individuals will place an increasing priority on continuous learning in order to stay competitive in the market. This is even more relevant to the Industrial Engineer.

Democratization of computing: Computing is becoming as common as driving an automobile. In some parts of the world it is even more common as people opt to not own and use their own transportation artifacts. This empowers individuals to make bigger contributions to the value adding processes of organisations.

Enterprise wide information sharing: With increased connectivity and cheaper storage and data collection equipment, an ever increasing amount of information is available throughout the enterprise. The competitive edge is obtained by those who optimally utilise this information.

Process oriented horizontal company structures: Companies are restructuring in the ever increasing global competition race. This normally implies empowered workers with the ability to compete on time to market, price, quality and product flexibility in the World Class Manufacturing Arena. 
- Customer satisfaction focused: The customer is "king" and competitors will even exchange non-critical production transformation information in an effort to improve productivity and efficiency.

- Maximum information sharing: The focus on World Class Manufacturing status forces management to share an increasing amount of information in a repositioned organizational structure.

\section{THREATS TO THE INDUSTRIAL ENGINEER}

The threats of the information revolution to the Industrial Engineer are summarized by the individual's inability to accommodate change. The Industrial Engineers who are not willing to adjust to the changes will be left behind in an arena where opportunities are utilised by those who understand the new era of the information age.

More specifically, the threats are situated in:

- A reluctance to sharing of power

- A reluctance to adapt to the continuous learning process.

- A reluctance to make costly investments and upgrading of personal and enterprise equipment.

- A reluctance to adapt to the continuous changes that are forced upon industry at an increasing rate, and that are inevitable if competitiveness and bottom line profits are important.

\section{OPPORTUNITIES FOR THE INDUSTRIAL ENGINEER}

The opportunities for the Industrial Engineer are lucrative and challenging. The training and skills of Industrial Engineers as system integrators and man-machine interface builders position them favourably to make maximum use of the information revolution. It is their duty to ensure that they:

- Contribute and share in developing opportunities within existing environments

- Become the agents to facilitate in planning the inevitable changes that will be required

- Become leaders in the interface between Industrial Engineering and Information technology

- Facilitate and Improve knowledge sharing

- Understand and facilitate empowering of employees as this will lead to more value added 
If the Industrial Engineer understands the key concepts of the Information age, then he can also focus with good results on those traditional issues that have contributed significantly to the improvements associated with the industrial age. These are as relevant and important as ever and should not be shortchanged. (Maybe the biggest threat of it all is that the new era Industrial Engineer is not capable of still doing sound pragmatic Industrial Engineering.) The key improvement factors still are: KEY FACTORS. However, they can now be integrated into a more holistic approach to improve quality, productivity and thus profitability. This is possible through more mature and integrated planning and control functionality being made possible by the Information Era.

\section{KEY IMPROVEMENT FACTORS OF THE INDUSTRIAL AGE}

The key improvement factors of the industrial age as listed by Konz (1984) are still relevant and must be integrated in any systems approaches to enterprise improvement. They are:

\subsection{IMPROVED PRODUCT DESIGN}

Improved product design led to improved productivity. The following were rectified:

- Improper design

- Non-standardization
- Incorrect quality standards

- Material wastage

\subsection{IMPROVED MANUFACTURING METHODS}

Manufacturing methods impacted the Industrial Revolution. This was done by focusing on:

- Incorrect tools

- Incorrect use of tools
- Incorrect methods

- Incorrect layouts

\subsection{IMPROVED MANAGEMENT}

The improvements in management were obtained by focusing on:

- Too wide variety of products

- Inadequate product design

- Poor production scheduling
- Inadequate maintenance

- Poor quality assurance

- Inadequate concern for working conditions

\subsection{IMPROVED WORKER OUTPUT}

The contributions of workers were obtained by addressing the problems of: 
- Late starters

- Absence without cause
- High scrap rates.

- Accidents through carelessness

\section{CONCLUSIONS}

The following conclusions were made:

Industrial Engineering has finally become empowered and reached a level of maturity that was greatly facilitated by the Information era. This is manifested in the ability to model and experiment on enterprise level, to co-ordinate and manufacture and compete on an international level and to continue to contribute towards wealth creation and improved utilization of resources.

The successful Industrial Engineer of the future will base his success on the efficiency with which he:

- Understand the Information era and its subtle and not so subtle differences from the Industrial era.

- Continue to improve his ability to find the latest resources and intellectual inventory globally, to add value and to re-use these resources optimally.

- Continue to understand those basic success factors of the Industrial Age and continue to integrate those "basic truths" into a modelling and control environment within the enterprise which will not become less complex or demanding.

To enable the Industrial Engineer of tomorrow to do this efffectively, training and education should focus on both the basic engineering principles and the global enterprise systems. This will empower the Industrial Engineer to fullfill their challenging role in modern society. 


\section{LITERATURE AND REFERENCE LIST}

\subsection{BOOKS}

1. Hillmann, J.E. et al, "Handbook of Engineering Management," John Wiley and Sons, 1986.

2. Juran, J.M. et al, "Juran's Quality Control Handbook," Fourth Edition, McGraw-Hill, 1988.

3. Konz, S., "Work Design: Industrial Ergonomics," Second Edition, Grid Publishing, Inc., 1979.

4. Salvendy, G., "Handbook of Industrial Engineering," Second Edition, John Wiley and Sons, 1992.

\subsection{ARTICLES}

1. Biniewicz, S.A. et al, "Advanced Technology and its Impact on Facility Planning," Industrial Engineering, Vol. 25, No.6, June 1993.

2. Derks, R.P., " Purpose-driven Product and Process Design," Industrial Engineering, Vol. 25, No.1, January 1993.

3. Gustin, C.M., "Examination of 10-year trends in Logistics Information Systems," Industrial Engineering, Vol. 25, No.12, December 1993.

4. Klein, M.M., "Re-engineering: Opportunity or threat for the I.E.?" Industrial Engineering, Vol. 25, No.9, September 1993.

5. Lee, S., "IE's at insight industries put their computer expertise to work," Industrial Engineering, Vol. 25, No.8, August 1993.

6. Ligus, R.G., "Methods to help re-engineer your company for improved agility," Industrial Engineering, Vol. 25, No.1, January 1993.

7. Lopes, P.F., "Fine-tuning re-engineering with workflow automation: Blueprinting and tool," Industrial Engineering, Vol. 25, No.8, August 1993.

8. McFarlane, D., "Enterprise-Wide Project Management," Industrial Engineering, Vol. 25, No.6, June 1993.

9. Pandiarajan, V. et al, "Agile Manufacturing: Economic Survival for the Future," Industrial Engineering, Vol. 26, No.2, February 1994.

10. Stewart, T.A., "The Information Age in Charts," Fortune, Vol. 129, No.7, April 4, 1994.

11. Turner, J.R., "Integrated supply chain management: What's Wrong with this Picture?" Industrial Engineering, Vol. 25, No.12, December 1993.

12. Noyons, E.C.M. et al, "De Informatietechnologie in Vlaanderen," Centrum voor Wetenschaps- en Technologie-Studies, 1994.

13. “Algemene Voorstelling van BELNET," BELNET info, Basisnummer ' 94.

14. "IT in Vląanderen," Vlaams Instituut voor de Bevordering van het Wetenschappelijk-Technologisch Onderzoek in de Industrie, December 1993. 


\subsection{INTERNET SOURCED DOCUMENTS}

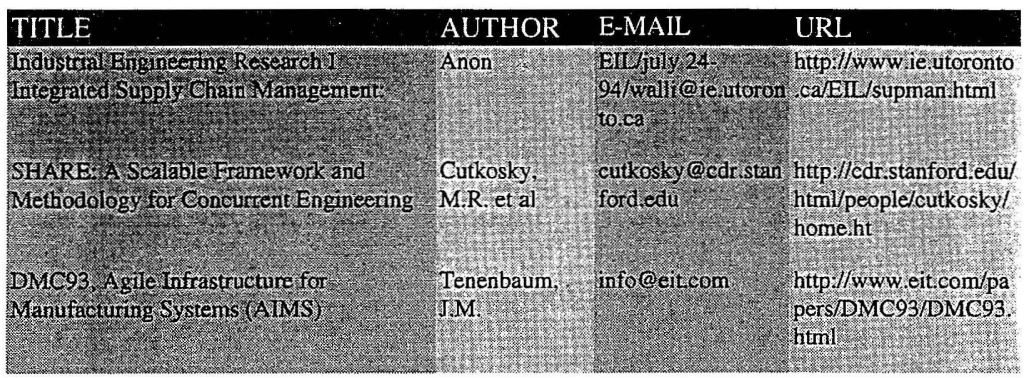

\subsection{GENERAL MATERIAL}

"Ford, Henry (Bibliography)," Microsoft (R) Encarta. Copyright (c) 1993 Microsoft Corporation. Copyright (c) 1993 Funk \& Wagnall's Corporation 


\section{APPENDIX A: results of the publications analysis- Condensed topics by major category.}

TABLE ONE: TOPICS ON THE CATEGORY: "DESIGN IN THE LARGE"

\begin{tabular}{|l|l|r|}
\hline Major Category & CONDENSED TOPIC & Total \\
\hline DESIGN-IN-THE-LARGE & Ergonomics & 14 \\
\cline { 2 - 3 } & Purpose Driven Design & 10 \\
\cline { 2 - 3 } & Simulation & 5 \\
\hline & Transformation management & 2 \\
\cline { 2 - 3 } & Concurrent engineering & 2 \\
\hline Facilities design & 2 \\
\hline & Logistics management & 2 \\
\cline { 2 - 3 } & Re-engineering & 1 \\
\hline & Agile Manufacturing & 1 \\
\hline & Environmental engineering & 1 \\
\hline HAZOP & 1 \\
\hline & IE Skills & 1 \\
\hline Knowledge based Manufacturing & 1 \\
\hline Manufacturing & 1 \\
\hline Strategic planning & 1 \\
\hline TQM & 1 \\
\hline Training & 1 \\
\hline WCM & 50 \\
\hline
\end{tabular}

TABLE TWO: TOPICS ON THE CATEGORY: "ENTERPRISE ENGINEERING"

\begin{tabular}{|c|c|c|}
\hline \multirow[t]{23}{*}{ ENTERPRISE ENGINEERING } & & \\
\hline & Re-engineering & 19 \\
\hline & WCM & 17 \\
\hline & TQM & 11 \\
\hline & Transformation management & 5 \\
\hline & Information management & 4 \\
\hline & Logistics management & 3 \\
\hline & Continuous Improvement & 2 \\
\hline & Enterprise engineering & 2 \\
\hline & Agile Manufacturing & 1 \\
\hline & Facilities design & 1 \\
\hline & Purpose Driven Design & 1 \\
\hline & Simulation & 1 \\
\hline & Strategic planning & 1 \\
\hline & Accounting & 1 \\
\hline & Configuration management & 1 \\
\hline & New Manufacturing strategy & 1 \\
\hline & Process flow & 1 \\
\hline & Project management & 1 \\
\hline & Software & 1 \\
\hline & Strategic management & 1 \\
\hline & Tactical planning & 1 \\
\hline & Totat & 76 \\
\hline
\end{tabular}


TABLE THREE: TOPICS ON THE CATEGORY: "ENTERPRISE INFORMATION ENGINEERING"

\begin{tabular}{|l|l|r|}
\hline ENTERPRISE INFORMATION ENGINEERING & Information management & 4 \\
\cline { 2 - 3 } & Simulation & 3 \\
\cline { 2 - 3 } & Software & 3 \\
\cline { 2 - 3 } & Logistics management & 1 \\
\hline & Purpose Driven Design & 1 \\
\hline WCM & 1 \\
\cline { 2 - 3 } & Information & 1 \\
\cline { 2 - 3 } & Tactical planning & Total \\
\cline { 2 - 3 }
\end{tabular}

TABLE FOUR: TOPICS ON THE CATEGORY: "INTEGRATED TRANSFORMATION ENGINEERING"

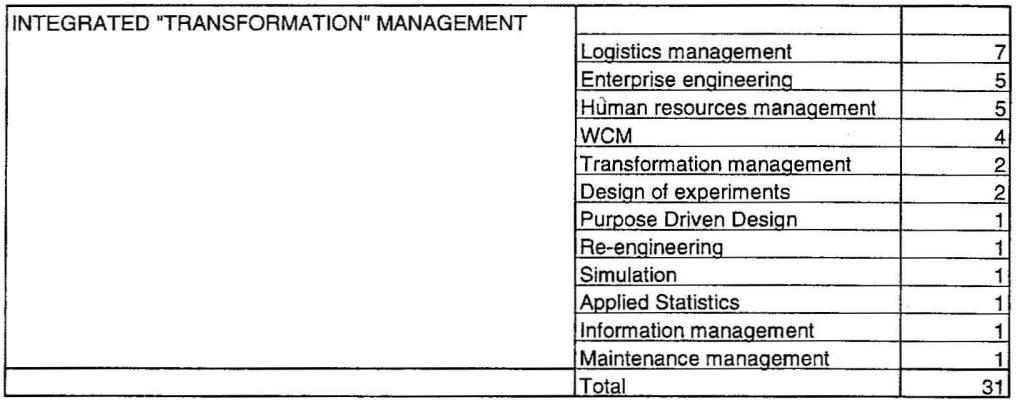

TABLE FIVE: TOPICS ON THE CATEGORY: "INDUSTRIAL ENGINEERING PROFESSION"

\begin{tabular}{|l|l|r|}
\hline THE INDUSTRIAL ENGINEERING PROFESSION & Simulation & 5 \\
\cline { 2 - 3 } & Re-engineering & 3 \\
\cline { 2 - 3 } & Environmental engineering & 2 \\
\hline & Continuous Improvement & 2 \\
\hline & IE skills & 2 \\
\hline & IE-skills & 2 \\
\hline & IE-profession & 1 \\
\hline & IE Skills & 1 \\
\cline { 2 - 3 } & Logistics management & 1 \\
\cline { 2 - 3 } & Purpose Driven Design & 1 \\
\cline { 2 - 3 } & Strategic planning & 1 \\
\hline & WCM & 24 \\
\hline
\end{tabular}




\section{APPENDIX B: The Industrial Engineering Time-line.}

\begin{tabular}{|c|c|c|}
\hline INITIATOR & TIMELINE & $\begin{array}{l}\text { EVENT, DEVELOPMENT OR } \\
\text { CONTRIBUTION } \\
\end{array}$ \\
\hline James Watt & 1764 & Steam Engine \\
\hline Whitney & 1798 & Interchangeable Parts \\
\hline Henry Maudsley & 1810 & Accurate machine tools \\
\hline $\begin{array}{l}\text { Michael Faraday and Joseph } \\
\text { Henry }\end{array}$ & 1812 & Dynamo, motor \\
\hline Ricardo & 1817 & Principles of Political Economy and Taxation \\
\hline Charles Babbage & 1832 & On the Economy of Machinery and \\
\hline Samuel Colt & 1835 & Assembly line \\
\hline Nikolaus Otto & 1876 & Internal combustion \\
\hline Thomas Edison & 1876 & Electric Illumination \\
\hline F.W. Taylor, Adam Smith & 1881 & Scientific management \\
\hline Frank and Lillian Gilbreth & 1885 & Motion Study, methods improvement \\
\hline Frederick Taylor & 1898 & Scientific work study \\
\hline Herman Hollerith & 1898 & Scientific Work Study \\
\hline James Gunn & 1901 & $\begin{array}{l}\text { First used term "Industrial Engineer" in The } \\
\text { Engineering magazine }\end{array}$ \\
\hline Louis Bandeis & 1930 & $\begin{array}{l}\text { First meeting of society to promote scientific } \\
\text { management. Brandeis used term "scientific } \\
\text { management" at ICC meetings }\end{array}$ \\
\hline Charles Going & 1911 & Book "Principles of Industrial Engineering" \\
\hline F.W.Taylor & 1911 & $\begin{array}{l}\text { Book "The principles of Scientific } \\
\text { Management" }\end{array}$ \\
\hline \multirow[t]{4}{*}{ Lee de Forest } & 1912 & Invented the Triode - Radio \\
\hline & 1914 & Gantt Chart applied in the Frankford Arsenal \\
\hline & 1917 & Society of Industrial Engineers formed \\
\hline & 1920 on & $\begin{array}{l}\text { Quantitative methods/ Expanded areas of } \\
\text { application }\end{array}$ \\
\hline Walter Shewhart & 1924 & Quality control charts by Shewhart \\
\hline Henry Ford & 1924 & Low cost Mass consumption \\
\hline $\begin{array}{l}\text { Walter Stewhart (Bell } \\
\text { Telephone laboratories) }\end{array}$ & 1931 & $\begin{array}{l}\text { "Economic Control of the quality of } \\
\text { Manufactured Product" }\end{array}$ \\
\hline \multirow[t]{2}{*}{ R Barnes } & 1933 & $\begin{array}{l}\text { First successful Ph.D. student in Industrial } \\
\text { Engineering in the USA (Cornell University) } \\
\text { Thesis later to be rewritten in book "Motion and } \\
\text { Time Study" }\end{array}$ \\
\hline & 1937 & $\begin{array}{l}\text { Allan Mogensen's Lake Placid work } \\
\text { simplification conference }\end{array}$ \\
\hline \multirow[t]{3}{*}{ Hawthorne Studies } & 1939 & Tweaking the work environment \\
\hline & 1944 & The American Society for Quality control \\
\hline & 1945 (end) & $\begin{array}{l}\text { PHASE ONE: Bettering Quality of life and } \\
\text { improving the use of resources }\end{array}$ \\
\hline Demming and Juran & 1946 & Quality era started \\
\hline \multirow[t]{2}{*}{ Wyllys Stanton } & 1948 & $\begin{array}{l}\text { American Institute of Industrial Engineers } \\
\text { founded. In June the first issue of The Journal of } \\
\text { Industrial Engineering was published. }\end{array}$ \\
\hline & 1948 & $\begin{array}{l}\text { The American Institute of Industrial Engineers } \\
\text { (AIIE) was founded in Columbus Ohio }\end{array}$ \\
\hline
\end{tabular}




\begin{tabular}{|c|c|c|}
\hline IN ITIATOR & TIM ELINE & $\begin{array}{l}\text { EVENT, DEVELOPM ENT OR } \\
\text { CONTR IB UTION }\end{array}$ \\
\hline & 1948 & $\begin{array}{l}\text { The American Institute of Industrial Engineers } \\
\text { (A IIE) was founded in Columbus O hio }\end{array}$ \\
\hline & $1950(\mathrm{circa})$ & $\begin{array}{l}\text { Transition from empirical operations research to } \\
\text { more quantifiable methods }\end{array}$ \\
\hline & 1950 & Start of scientific base for Industrial Engineering \\
\hline & $1950^{\prime} s$ & $\begin{array}{l}\text { Establishment of the Institute for M anagement } \\
\text { Sciences of A merica TIMS }\end{array}$ \\
\hline & $1950^{\prime} \mathrm{s}$ & $\begin{array}{l}\text { Establishment of the Operations Research Society } \\
\text { of America (ORSA) }\end{array}$ \\
\hline & 1956 & $\begin{array}{l}\text { A PICS The American Production and Inventory } \\
\text { control Society }\end{array}$ \\
\hline Donald $\mathrm{Malcolm}$ & I960's & Network A nalysis (PERT) \\
\hline \multirow[t]{5}{*}{ John White } & 1960 's & Materials $\mathrm{H}$ and ling handbook \\
\hline & 1960 's & $\begin{array}{l}\text { Ability (computer) to experiment with larger } \\
\text { systems }\end{array}$ \\
\hline & 1960 's & A bility to store and retrieve information \\
\hline & 1960 's & High speed, stored program digital computer \\
\hline & 1940 's & Simplex method for LP \\
\hline A lan Pritsker & 1960 & Simulation modelling \\
\hline \multirow[t]{2}{*}{ Orlicky } & 1960 & Material requirements planning (M RP) \\
\hline & 1960 & $\begin{array}{l}\text { IE Curricula became more Mathematical modelling } \\
\text { oriented }\end{array}$ \\
\hline \multirow[t]{2}{*}{ Lunar Landing } & 1967 & Communications \\
\hline & 1969 & $\begin{array}{l}\text { First issue of "Industrial Engineering"- The official } \\
\text { publication of the A merican Institute of Industrial } \\
\text { Engineers. }\end{array}$ \\
\hline $\begin{array}{l}\mathrm{N} \text { ippon Denso auto'parts } \\
\text { manufacturer }\end{array}$ & 1971 & Total Productive maintenance \\
\hline Industria I Enginee ring & 1971 & $\begin{array}{l}\text { "M aintenance scheduling becomes popular. It } \\
\text { relieves schedulers from manual sorting and slotting } \\
\text { scheduling routines" }\end{array}$ \\
\hline Industrial Engineering & 1972 & $\begin{array}{l}\text { The greatest example and achievement of } \\
\text { participative management is achieved in Japan:- } \\
\text { QC C irles }\end{array}$ \\
\hline Industrial Enginee ring & 1972 & $\begin{array}{l}\text { Shift towards the service sector where more and } \\
\text { more money is spend }\end{array}$ \\
\hline Toyota Motor Company & 1973 & $\begin{array}{l}\text { Just In Time Production (Toyota production } \\
\text { system) }\end{array}$ \\
\hline \multirow[t]{2}{*}{ Personal computers } & 1978 & \\
\hline & 1979 & M anufacturing Resources planning (MRP II) \\
\hline Industrial Engineering & 1984 & $\begin{array}{l}\text { Computer Integrated Manufacturing Systems (CIM } \\
\text { integrated with CAD/C AM) encompasses all } \\
\text { activities from planning and design of a product to } \\
\text { its manufacturing and shipping. }\end{array}$ \\
\hline \multirow[t]{3}{*}{ Hypertext } & 1985 & \\
\hline & 1989 & Information Revolution \\
\hline & 1989 & $\begin{array}{l}\text { Three high-end LP software systems (OSL from } \\
\text { IBM, CPlex from Rice university, OB l from } \\
\text { Rutgers university) }\end{array}$ \\
\hline Industrial Engineering & 1991 & $\begin{array}{l}\text { Currently } 55 \text { countries worldwide have adopted } \\
\text { ISO } 9000 \text { standard }\end{array}$ \\
\hline DR. M ichael Hammer & 1991 & $\begin{array}{l}\text { Re-engineering introduces the start of the enterprise } \\
\text { engineering field }\end{array}$ \\
\hline Industrial Enginee ring & 1992 & $\begin{array}{l}\text { The application of simulation extend beyond the } \\
\text { current uses to become part of end integral with } \\
\text { the daliy operation of tactories }\end{array}$ \\
\hline University of Toronto & current & Integrated Enterprise engineering \\
\hline
\end{tabular}

